\title{
ISLAMIC EDUCATION THOUGHT OF SHEIKH NAWAWI AL-BANTANI: THE DISASTER IN THE QUR'AN
}

\author{
Maragustam \\ State Islamic University of Sunan Kalijaga Yogyakarta \\ Email: maragustam@uin-suka.ac.id
}

\begin{abstract}
Nawawi is a true teacher in Islamic science and very prolific in writing Islamic science. The purposes of this study are (1) to find out the characteristics of the plague in Nawawi's thinking; (2) to propose the solution to the Covid-19 outbreak from the perspective of Islamic education; (3) to figure out the Islamic education from this pandemic. This study employed qualitative research from an Islamic education philosophy perspective. The data collection was documentation. It also used content analysis, thematic, and inductive-deductive approaches. There are some findings in this research. First, the words calamity, Bala, and slander, the pandemic, is a test. It happened as a result of the power of God and the work of man. The purpose is for man to be closer to God, more meaningful to God's presence, erode pride, etc. Second, it is not permissible to approach the place of plague. If it is at the epidemic site, then do not come out of it; the sick do not mix with the healthy, avoid harming themselves and others, and put the damage off rather than benefit. Third, the values of Islamic education are spiritual, intellectual, social, and skill.
\end{abstract}

Abstrak: Nawawi adalah mahaguru sejati dalam keilmuan Islam dan sangat produktif menulis bidang keilmuan Islam. Tulisan ini menjawab (1) karakteristik wabah dalam pemikiran Nawawi; (2) solusi dari wabah Covid-19 dalam perspektif pendidikan Islam; (3) nilai-nilai pendidikan Islam yang diperoleh dari pandemi ini. Penelitian ini menggunakan metode penelitian kualitatif dengan pendekatan filsafat pendidikan Islam. Pengumpulan data dalam penelitian ini menggunakan dokumentasi. Penelitian ini menggunakan analisis isi, tematik, dan pola pikir induktif-deduktif. Hasil temuan dalam penelitian ini adalah pertama, merujuk kepada kata musibah, bala, dan fitnah, pandemi merupakan ujian. Hal itu terjadi sebagai akibat kuasa Allah dan ulah manusia. Tujuannya agar manusia lebih dekat kepada Allah, lebih bermakna kehadiran Tuhan, mengikis kesombongan, dan lain-lain. Kedua, tidak boleh mendekati tempat wabah dan jika berada di lokasi wabah, maka jangan keluar darinya, yang sakit jangan bercampur dengan yang sehat, menghindari mudarat terhadap diri sendiri dan orang lain, dan mendahulukan menutup kemudaratan daripada mengambil manfaat. Ketiga, nilai-nilai 
pendidikan Islam ialah nilai spiritual, intelektual, sosial, dan keterampilan.

Keywords: Covid-19; slander the plague; Islamic education

\section{INTRODUCTION}

The author's academic anxiety, who chose Sheikh Nawawi (from now on called Nawawi), is the object of study: First, it has a legacy of monumental works. The works are still legible, and scientifically accountable works are the original work. Second, the character of Nawawi has been widely acknowledged; he is a regional and national caliber and an international caliber. In the Islamic world, especially in Indonesia, Nawawi is often mentioned as a respected religious leader and strongly influences society. Besides, he is a prominent scholar in Masjid alHaram. He is also a prolific author of the book ${ }^{1}$ and the Indonesian Islamic community leader in Mecca. Even the name Nawawi is one of the many figures in the scholarly field listed in the Munjid dictionary. ${ }^{2}$ Also, Nawawi lived in the renewal of the Islamic thought declared by Abduh (1849-1905) in Egypt. The declaration in the 19th century was undoubtedly influential in the science of Nawawi. ${ }^{3}$ Thirdly, about 100 are mostly Sharh of previous clerical works, even though it has an original thought. Indeed, the scholarly tendency of Islam in the 13th century $\mathrm{H}$ still encompasses the traditional taqlid. Cheap Tafseer is probably his original monumental work. Karel A. Steenbrink said that he compared the Tafsir Jalalain, Tafseer Baidhawi, the cheap Tafseer, and Tafseer al-Nur. It concludes that the job of Nawawi was much better and complete. ${ }^{4}$ According to Azra, such works of Sharh and Hasyiyah contain absolute originality. ${ }^{5}$

Therefore, the researcher eagerly to investigates (1) the characteristics of the plague in Nawawi's thinking; (2) the solution to the Covid-19 outbreak from the perspective of Islamic education; (3) the values of Islamic education from this pandemic. Nawawi was a true teacher, but his thoughts on the plague in the focus of plague studies were still scattered throughout various works. So the purpose of this paper wants to find and test, then construct it into a whole concept building.

1 Snouck Hurgronje, Mekka, Tn The Latter Part Of The 19TH Century (Leiden: Brill, 1931), 269.

2 Loes Ma'luf, Al-Munjid Fi al-Lughah Wa al-A’lam (Beirut: Darul Masyriq, 1987), 581.

3 Deliar Noer, Gerakan Moderen Islam Di Indonesia 1900-1942 (Jakarta: LP3ES, 1982), 39.

4 Ma'ruf Amin and M. Nasruddin Anshori CH, "Pemikiran Syekh Nawawi Al-Bantani," Pesasntren No. 1 Vol. VI/1989 (1989): 105.

5 Azyumardi Azra, Pendidikan Islam, Tradisi Dan Modernisasi Menuju Milenium Baru (Jakarta: Logos Wacana Ilmu, 1999), 11 dan 116. 


\section{RESEARCH METHODS}

This study employed a qualitative approach. It dealt with Islamic education. Moreover, the primary data source was Nawawi's work. The secondary sources were books, journals, or others related to Nawawi. The data collected through documents. The data analysis used content analysis, hermeneutic, and thematic interpretation.

\section{THEORETICAL REVIEW}

Fadli's research at the madrasah level showed that the anthropocentric approach (integration of godliness, humanity, and naturalness) had been implemented quite well). ${ }^{6}$ The connectedness of the Qur'an, science, and human spirituality will produce reliable resources in applying science and being able to face life. Islam guides people to worship God through the development and mastery of science. There are more than 800 verses of the Qur'an emphasizing the process of contemplation, thought, and observation of various symptoms of nature, to meditate, and to be a material of remembrance (remember) to God. The QurПan is a science book or can be considered an encyclopedia of science. ${ }^{7}$ It suggests that analyzing natural phenomena, including overcoming outbreaks, should dialogue between religious values, humanitarian values, and science.

Rahmatullah's research that Sufism-based spiritual education can be a motivation to worship, strengthen the spirit of the students, and be a motivation to avoid homosexual acts and motivate positive behavior. ${ }^{8}$ It means that religiousspiritual values are fundamental to deal with various deviant behaviors or difficulties in life such as plague, homosexuality, etc. Ahmadi's research found that internalizing attitudes and values is more likely through educational and teaching activities. In general, the internalization process aspects of attitudes and values in IAIN Ponorogo tend to be embedded and begin to develop. At the same time, in INSURI Ponorogo, some have started to develop, and some are just beginning to look. ${ }^{9}$ It means that those ingrained values will affect one's attitudes and behaviors in his life.

${ }^{6}$ Wirawan Fadly et al., "Diagnostic Skill of Internalization-Interconnection Qur'ani With Science in Three Levels of Madrasah," Cendekia: Jurnal Kependidikan Dan Kemasyarakatan 18, no. 2 (December 10, 2020): 267, https://doi.org/10.21154/cendekia.v18i2.2178.

7 Fadly et al., 273.

8 Azzam Syukur Rahmatullah and Muhammad Azhar, "Pendidikan Spiritual Berbasis Tasawuf (Upaya Meminimalisir Perilaku Menyimpang Homoseksual di Pesantren)," Cendekia: Jurnal Kependidikan dan Kemasyarakatan 17, no. 2 (November 5, 2019): 249, https://doi. org/10.21154/cendekia.v17i2.1746.

9 Ahmadi, Basuki, and Edi Irawan, "The Internalization of Attitude and Values: Comparison Study in PTKIN and PTKIS," Cendekia: Jurnal Kependidikan Dan Kemasyarakatan 18, no. 1 (May 16, 2020): 17, https://doi.org/10.21154/cendekia.v1i1.1761. 
Salim's research results that religious values become a symbolic reality in humanity and the social activities of the society. The ability to build value through the objectivization of religious values is an orderly norm for restoring human life towards the meaning of life. _It means that religious values can be symbolic of humanity and community activities. Building religious values can be one of the solutions to the restoration of human life. Mahmud Arif's research that our education system is less productive produces good output. Al-Kailani is troubling this and encourages the Islamic education system to contribute and participate in solving important educational problems based on the explanation of the Quran. Al-Kilani introduced the "triadic concept" of connecting spiritualtranscendental vision, anthropo-cosmological consciousness, and scientific rules. ${ }^{10}$

Ahmad and Ahad's research results that the sanitary measures suggested by modern medical science seem to be part of the daily routine of Muslims. Islam and science recommend similar scientific precautions to mitigate the adverse effects of this pandemic. It is the religious duty of every Muslim. ${ }^{11}$ It means that religious teachings provide guidance and a basis for science and humanity in dealing with the plague. Suyadi's research that Muhammadiyah's theological movement in the form of religious giving reconstructs the classical Islamic jurisprudence of the rules of worship to adapt to the emergency of the Covid-19 pandemic. ${ }^{12}$ It means that in overcoming the plague, in addition to medical and educational means, it must also be approached with religion, especially Islam, through the fiqh of worship. These theories show there is an interconnection between religious values, human values, and scientific rules.

\section{FINDINGS AND DISCUSSION}

\section{The Fact of Disaster in the Idea of Nawawi}

The Koran for man is not for God. Also, the Koran is open and inclusive. So everyone who has expertise can analyze the Qur'an scientifically, including analyzing the nature of disasters in the Koran. It agrees with the opinions of Fajlur Rahman and Farid Esack. They both acknowledge the existence of salvation in every religion while weighing the uniqueness of Islam. Rahman, for example,

${ }^{10}$ Zohaib Ahmad and Arzoo Ahad, "COVID-19: A Study of Islamic and Scientific Perspectives," Theology and Science 19, no. 1 (January 2, 2021): 39, https://doi.org/10.1080/1 4746700.2020.1825192.

${ }^{11}$ Mahmud Arif, “A Critical Conceptualization with Special Reference to Al-Kil[ni’s,” n.d., 15.

${ }^{12}$ Suyadi, Zalik Nuryana, and Niki Alma Febriana Fauzi, "The Fiqh of Disaster: The Mitigation of Covid-19 in the Perspective of Islamic Education-Neuroscience," International Journal of Disaster Risk Reduction 51 (December 1, 2020): 51, https://doi.org/10.1016/j. ijdrr.2020.101848. 
refers to the two logic of universal virtue that guarantees eschatological safety for all religious communities, as explicit in the Q.S. Al-Baqarah [2]: 62, Faith (trust in God and the Last day) and good deeds. According to Rahman, this logic of virtue disclaimers the attitudes of Jewish exclusivity and Christians claiming to be the sole owner of the truth and the Way of Salvation (QS. 2:113.119, 135). ${ }^{13}$ In connection with the disaster, three keywords in the Koran refer to the notion of calamity or plague of calamity, slander, and epidemics. The meaning of misfortune and catastrophe in the Indonesian dictionary is the same. Trouble means wretched or catastrophe. ${ }^{14}$ At the same time, the word Bala (tragedy) means disaster, Accident Tribulation. ${ }^{15}$

The word defamation leads to a lying name for people. ${ }^{16}$ But if you look at the impact, these three words always lead to misery, suffering, distress, confusion, and panic. With the thematic interpretation tools and associate it with the Covid-19, what are the characteristics of these three words in the Qur'an, the interpretation perspective of Nawawi.

The first is calamity. In the Thesaurus dictionary, the sense of calamity is sorrow, adversity, sadness, distress, suffering, etc. ${ }^{17}$ In KUBI, the catastrophe is wretched; Disaster Plagues Plague. ${ }^{18}$ To explore more in the meaning of "calamity," the author took a paragraph considered representative of Q.S. AlBaqarah (2): 156; Ali Imran (3): 165; Al-Nisa (4): 62 and 79; Al-Rum (3): 48; Luqman (31): 17; Al-Hadid (57): 22 and Al-Tagabun (64): 11.

According to Nawawi (Ali Imran (3): 165), the calamity that strikes Muslims in the war of Uhud is because Muslims do Maksiat, leave the center of defense, and greed against the treasures of Ganimah (the loot of war). ${ }^{19}$ In the sense of calamity (Luqman (31): 17) is a severe matter of both carrying out the order and leaving its Run. ${ }^{20}$ The catastrophe occurred to the Hypocritans (Al-Nisa (4): 62 and 79) as a result of their sign of deciding the matter by following the Thagut (Syetan) and turning away from the laws of God. ${ }^{21}$ In Al-Baqarah (2): 146 and

${ }^{13}$ Hendar Riyadi, "Koeksistensi Damai Dalam Masyarakat Muslim Modernis," Wawasan: Jurnal Ilmiah Agama Dan Sosial Budaya 1, no. 1 (February 1, 2016): 23, https://doi. org/10.15575/jw.v1i1.575.

${ }^{14}$ W.J.S. Poerwadarminta, Kamus Umum Bahasa Indonesia, Edisi III (Jakarta: Balai Pustaka, 2005), 787.

${ }^{15}$ Poerwadarminta, 85.

16 Poerwadarminta, 331.

${ }^{17}$ Eko Endarmoko, Tesaurus Bahasa Indonesia, Cetakan kedua (Jakarta: PT Gramedia, 2007), 423.

${ }^{18}$ Poerwadarminta, Kamus Umum Bahasa Indonesia, 787.

${ }^{19}$ Syekh Nawawi Bantani al, Murah Labiid Tafsir li Kasyf Ma'na Qur'an Majid, vol. Juz 1 (Mesir: Dar Ihya al-Kutb al-Arabiyah li Ashhabiha 'Isa al-Bab al-Halabi wa Syurakah, tt.), 128.

${ }^{20}$ Bantani al, Juz 1:171.

${ }^{21}$ Bantani al, Juz 1:157 dan 162. 
Al-Hadid (57): 22 that the direct calamity of God through Sunnatullah (the laws of God which are in the enactment of the universe).

According to Nawawi, the purpose of the calamity (the test) is to see the quality of one's Faith whether or not he will accept disaster or surrender to God's decree. All disasters come from God, written in Lauh Mahfuz. ${ }^{22}$ Calamity is the authority of God as such in Al-Taghabun (64): 11 and Al-Rum (30): 168. It means that it does not overwrite a calamity (plague) on someone except for God's permission. According to Nawawi, that calamity would not befall anyone, whether it relates to religion or in the flesh, such as bodies, families, and possessions, except for God's permission of his destiny and will. Asbab al-Nuzul This verse relates to the heathen, who said: If the Muslims are true certainly, God kept them from the calamity in the world. ${ }^{23}$

The purpose of calamity is to test man's patience. It also measures the extent to which men surrender to God; he did not mourn when God plucked what he had and was not proud or too merry when he had the favor. According to Nawawi, when explaining the Prophet's hadiths that people experience disasters, including covid-19, he must be patient. If a person is afflicted with a misfortune, then do not complain and be patient and wait for space; then that is one of the essential worship acts. Be patient when disaster strikes. ${ }^{24}$

The various characteristics of calamity, then can the author describe that the nature of the disaster is a test (not torture) with something that is not pleasing. It is a result of men or the consequences of the power of God through Sunnatullah (the laws of God which are in charge of the universe) or the consequences of the response that God set through his sunnah. The calamity (the test) not only befalls the wicked but also afflicts the obedient. The catastrophe, in this sense, is not tortured. Because the accident meant "torment," then surely only befall the criminals. The Covid-19 pandemic struck Muslims and Nonmuslims, who were obedient and ungodly. Regarding the epidemic, Covid-19 is the test, not the unpreparedness. It is in line with Quraish Shihab's opinion that if God drops the torment of a clan. He first rescued his obedient servants that they should not be overridden. ${ }^{25}$ The fact of the Empiric that this Covid-19 befalls The obedient and the ungodly. Hence the Covid-19 is not a torment but a test.

The second is bala'. The essence of the Nawawi's opinion about the Bala is an unpleasant or unpleasant exam (not a torment) that comes directly from

22 Bantani al, Juz 1:41 dan Juz 2:354.

${ }^{23}$ Syekh Nawawi Bantani al, Murah Labiid Tafsir Li Kasyf Ma'na Qur'an Majid, vol. Juz 2 (Mesir: Dar Ihyaal-Kutb al-Arabiyah li Ashhabiha 'Isa al-Bab al-Halabi wa Syurakah, tt.), 168.

${ }^{24}$ Syekh Nawawi Bantani al, Tanqih Al-Qaul al-Hatsits Fi Syarh Lubab al-Hadits (Semarang: Thaha Putra, tth.), 62-63.

${ }^{25}$ M. Quraish Shihab, Corona Ujian Tuhan Sikap Muslim Menghadapinya (Ciputat Tengerang Selatan: PT. Lentera Hati, 2020), 7. 
God without human involvement. But more (test) to the uncomfortable. Pandemic Covid-19 includes an unpleasant (analysis) Bala. Bala means disaster, misappropriation, Mala, calamity, calamity, and others in the Thesaurus dictionary. ${ }^{26}$ In KUBI, that Bala is a calamity; Accident Tribulation. ${ }^{27}$

Representation of the meaning of Bala taken from Q.S. Al-Baqarah (2): 49 and 155; Al-A'raf (7): 141; Ibrahim (14): 6; Al-Kahfi (18): 7; Muhammad (47): 31; And Al-Fajr (89): 15-16. The word "Bala" in Al-Baqarah (2): 49 in Nawawi about Fir'aun who saw the fire from the temple of Al-Muqoddas burned the houses of the Qibti peoples in Egypt, and the remaining are the houses of the children of Israel. So he called the scholars about the intent of his dream. It is explained that there will be a son of the children of Israel who will destroy the QIBTI and destroy your power in his hand. Responding to the prediction, Fir'aun ordered killing every boy born from Israel's children until he killed as many as 112 children. ${ }^{28}$ God delivered Israel's children from the great host (QS. Ibrahim (14): 433). The word Bala is not only used for something unpleasant but also something fun (QS. Al-Kahfi [18]: 7 and Al-Fajr (No. 89): 15-16). Whether pleasant or not, keep the Bala straight from the Lord. The aim of the test, according to Nawawi, measures the quality of Faith, who is most obedient to God, and the extent of Istiqamah's devotion to him. ${ }^{29}$ The Taklif is also a direct one from God (Muhammad [47]: 31) to test the quality of Faith, the quality of jihad, and the patience of the severity of Jihad Fisabilillah. ${ }^{30}$

The third is slander. Defamatory means test or disaster. The birth of slander is a human being either derived from an individual or a group, but its effects on sinners, unrighteous (Thalih), and right (righteous) people. In Thesaurus dictionary, slander means blasphemy, defamatory means worsening, dildoing, lousy mouth, and others. ${ }^{31}$ In KUBI that defamation is a word of lying that is intended to insure people. ${ }^{32}$

To trace the meaning of defamation, the author chooses Q.S. Al-Anfal (8): 25 and 28; Al-Furqan (25): 20 and Al-Anbiya (21): 35. On the Q.S. Al-Anfal (8): 25 and Al-Furqan (25): 35 It is mentioned that slander not only befalls the unsettled and wronged but afflicted the other, both Individual and the group. According to Nawawi, slander not only overwrote the wrongdoers but overcame the whole (righteous and unrighteous). To avoid such deformation, Islam Require prohibits Nahi Munkar. Everyone who sees libel is obliged to eliminate

\footnotetext{
${ }^{26}$ Endarmoko, Tesaurus Bahasa Indonesia, 50.

${ }^{27}$ Poerwadarminta, Kamus Umum Bahasa Indonesia, 85.

${ }^{28}$ Bantani al, Murah Labiid Tafsir li Kasyf Ma'na Qur'an Majid, Juz 1:13.

${ }^{29}$ Bantani al, Juz 1:492.

${ }^{30}$ Bantani al, Murah Labiid Tafsir Li Kasyf Ma'na Qur'an Majid, Juz 2:302.

${ }^{31}$ Endarmoko, Tesaurus Bahasa Indonesia, 180.

${ }^{32}$ Poerwadarminta, Kamus Umum Bahasa Indonesia, 331.
} 
it when he powers it. If he has done it, then both the wrongdoers and the not, all in a state of sinning because these are good people if they do not prevent people from sinning, as if they were to discourage it.

Allah makes the defamatory person by doing so, then to bear the slander (test). ${ }^{33}$ It also relates to the Q.S. Al-Anfal (8): 28 Explains that property and children are also defamatory (exam). Nawawi said that children and possessions were a test of God. So one never has to be because of love, and his passion makes him traitorous and brings orgasm. ${ }^{34}$ The purpose of defamation, according to Nawawi (Al-Anbiya 21:35), is to test. Suppose one is patient when it is overwritten by unpleasant (Al-Shar) and grateful when awarded something pleasing (al-Khair) or not appreciative. ${ }^{35}$ Defamation is a non-tortious test, which can occur in any person, individual, or group, Muslim and Nonmuslim, obedient and ungodly. Defamation can be misery or pleasure. Defamation aims to test patience if the slander is misery and meaningfulness if the libel is excitement.

\section{The Solution of Plague, such as Covid-19}

The disaster can be due to the power of God. As a result of human behavior such as violating Sunnatullah (the laws of God which are in the cause of the universe), break the commandments of God, natural disaster. The power of God directly lowers the plague test to humankind. It can be seen from the scientific findings that catastrophe can occur from the consequences of natural disasters. Humanmade disasters can also cause it. ${ }^{36}$ Natural disaster in Islam is known as God's fate directly or through Sunnatullah, such as the Covid-19. Simultaneously, the tragedy resulting from a human-made disaster can be environmental damage, social conflict, terrorist/sabotage, and pain/death, such as a Covid-19 outbreak.

Paulinus Yan Olla, quoted by Maragustam, said that the various kinds of disasters in this country are not God's curse. However, human creation is driven to the greed of power, greed of wealth, and thirst to seek the glory of oneself. ${ }^{37}$

The self-respect associated with Covid-19 can be greed against eating land and sea animals, such as snakes, bats, etc. Concerning humans' consequences, initially, the Covid-19 was transmitted between animals and humans as SARS is transmitted from the mongoose to humans. In contrast, MERS is transmitted to

${ }^{33}$ Bantani al, Murah Labiid Tafsir li Kasyf Ma'na Qur'an Majid, Juz 1:318.

${ }^{34}$ Bantani al, Juz 1:319.

${ }^{35}$ Bantani al, Murah Labiid Tafsir Li Kasyf Ma'na Qur'an Majid, Juz 2:37.

${ }^{36}$ Kementerian Negara PPN /Bappenas RI Bappenas RI, Rencana Aksi Nasional Pengurangan Resiko Bencana 2006-2010 (Jakarta: Bappenas dan Bakornas PB, 2006), 1.

${ }^{37}$ Maragustam Siregar, "Bencana dalam Al-Qur'an (Pemikiran Pendidikan Al-Qur'an Berbasis Bencana)," Jurusan Tafsir Hadis Fak. Ushuluddin UIN Sunan Kalijaga 8,No. 1 Januari 2007 (2007): 59-80, http://digilib.uin-suka.ac.id/24133/1/bencana\%20dalam\%20alquranmaragustam\%20fix.pdf. 
humans through camels. ${ }^{38}$ The Virus is known to first appearing in the animal and seafood markets in Wuhan City. Thus, the most likely cause of the Covid-19 disaster is God's creation through human greed in consuming animals such as snakes, bats, chickens, seafood, etc.

\section{Principle of Islamic Education from Covid-19 Outbreak}

People in education occupy a central position because humans are also seen as education objects and viewed as subjects. There are two traditions in the development of Islamic thought. First is the flow of fatalism or Steinman's pattern, and second, a patterned stream of free will and complimentary act. God creates the understanding of fatalism, the will, the potential, and the deeds of man. Man is merely an executive of the will of God. While understanding free will is the opposite: will, willpower, and man determines human acts. ${ }^{39}$

Human understanding in theology also implicates the flow of philosophy of Islamic education sourced from the word Fitrah (QS. Rum: 30). The tide is a fatalist-passive, neutral-passive, positive-active, and dualist-active. ${ }^{40}$ Among the streams that best fit the outbreak of Covid-19 is the positive-active or Dualisactive. The positive-active characteristic is (1) man brings essential potential, and pure tendency to good things, (2) on one side of the environment can affect a person, and on the other hand, man can reject it or partially accepted and partly ridiculed (3) God gives freedom to man to behave and act, and (4) if a person is of good character, then it is by his fundamental innate and integral part of himself, on the contrary, if a man is not in character, then it is not an integral part of him nor is god's will. ${ }^{41}$ While the characteristics of Dualis-Active are (1) man brings essential potential and pure tendency to positive and negative, (2) on one side of the environment can affect a person, and on the other hand, man can reject it or partially accepted and partially ridiculed, (3) God gives freedom to man to behave and act, and (4) if a person is of good character, then it is in line with the fundamental innate and integral part of himself, on the contrary, if a man is not in character, then it is also an integral part of him and not the will of God. ${ }^{42}$

The two theories imply that when the Covid-19 disaster befalls a person, people are looking for a solution to overcome it. With Dualis-active and positive-

${ }^{38}$ Ega Almira Shae, "Virus Corona: Penyebab, Cara Pencegahan Dan Dampaknya Pada Ekonomi Global Avatar,” Koinworks, 2020, https://koinworks.com/blog/virus-corona/.

${ }^{39}$ Harun Nasution, Teologi Islam, Aliran-Aliran Sejarah Analisa Perbandingan (Jakarta: UI-Press, 1986), 116.

${ }^{40}$ Maragustam, Filsafat Pendidikan Islam Menuju Pembentukan Karakter (Yogyakarta: FITK UIN Sunan Kalijaga, 2020), 128-36.

${ }^{41}$ Maragustam, 94-95.

${ }^{42}$ Maragustam, 94-99. 
human-active theories, humans are continuously trying to find solutions out of this Covid-19 exam. Humans are not passive but active in creating strategic plans of various elements. It is considered to reduce the A and risk of catastrophic Covid-19 in a community, respond, prevent (preventive), and mitigate (mitigation) unwanted impacts of threats in the broad context of sustainable development.

Islamic education generally provides solutions facing Covid-19. First is by avoiding the disaster or the plague, "do not approach the place where the plague is in, and if you are already at the site of the plague, then do not exit the site of the plague." Do not knock yourself into destruction (QS. Al-Baqarah: 195). According to Sheikh Nawawi, do not plunge yourself into destruction by preventing spending on God's way, excessive spending on wealth, or wasting livelihoods. ${ }^{43}$ From the dimensions of the results, that the human being character or being a character tuna, it is already an integral part of him and equipped with an environmental coating. And do not kill yourselves; Indeed, Allah is most merciful to you. Q.S. Al-Nisa: 29). That is not to do deeds that cause you to die, like killing believers without reason, apostate, and Zina Muhshan. ${ }^{44}$ Avoiding the plague of Covid-19 is included in the scope not to waste life and not commit the deeds that cause death. The two verses are evidence that everyone must avoid the plague that has dropped himself to destruction. ${ }^{45}$ In addition to the Qur'an verses, also in Hadith mentioned: Rasulullah SAW said: "Tha'un (outbreaks of infectious diseases) is a reminder of Allah to test his servants from the people. So if you hear the disease contracting in a land, do not enter the area. And if the plague is infected in the place where you are, do not flee from it. " HR. by Al-Bukhari and Muslim from Usamah ibn Zaid.

The next is avoiding the plague using "the sick do not be cast out with a healthy one or should not commit or inflict a madhorot against oneself and others." In Hadith, it says, "Do not the sick are mixed with the healthy" (HR. by Al-Bukhaari and Muslim). "It is not permissible to do Madhorot and give madhorot to oneself and others." HR. By Ibn Maajah and Ahmad ibn Hanbal.

It is avoiding the plague using "closing the damage more precedence than taking advantage." In the rule of Ushul, Fiqh is said to be "Dar'u al-mafaasid muqaddam "ala jalb al-Mashaalih" 46 (leaving damage precedence over taking principles or benefits). For example, the congregation in the mosque gives benefits, while the Covid-19 is endangering even deadly. So avoiding the plague

${ }^{43}$ Bantani al, Murah Labiid Tafsir li Kasyf Ma'na Qur'an Majid, Juz 1:51.

${ }^{44}$ Bantani al, Juz 1:148.

${ }^{45}$ Mas'ud Sabiry, Fatawaa Al-Ulama Haula Firus Corona (At Tawzi’ Wa al-Nasyar, 2020), 16.

${ }^{46}$ Djazuli A., Ushul Fiqh Metodologi Hukum Islam (Jakarta: PT RajaGrafindo Persada, 2000), 155. 
of Covid-19 takes precedence over earning rewards in the congregation in the mosque. Likewise, religion introduces Dharuriy, Hajjy, and Kamaliyat. Dharuriy (which must exist for the benefit of religion and the world) has five, namely Hifdh al-Din, Hifdz al-Nafs, Hafdz al-Aql, Hifdz al-NASL, and Hifdz al-Maal. In Hifdz al-Nafs (Nurturing the soul), a rule applies that can leave something required by religion if it destroys the soul. The example can not pray Friday (replaced with Zuhur prayer) When Friday prayers endanger the soul due to the outbreak of the Covid-19.

\section{Values of Islamic Education in the Covid-19 Pandemic}

The three general education principles can be more detailed to Islamic education's four values: religious-spiritual, cognitive, affective, and psychomotor. The first is the educational dimension of religious, spiritual value. Spiritually, the personal views and behaviors that express the sense of association and consciousness to God's metaphysical dimension understand life's meaning and nature. Religious or Faith spiritual is at the heart of moral consequence. Moral conscience is a ruhaniah force of encouragement to a person to do praises and prevent him from committing evil. ${ }^{47}$ Spiritual or Faith in the heart will cause logical consequences of mental actions in the form of experiences of Islamic norms (moral judgment), moral responsibility (moral responsibility), and moral rewards. Spiritual intelligence is the ability to understand the meaning and value of disaster screams, the fundamental wisdom that it contains, and the ability to self-regulate the disaster screams. According to Ibn Qayyim, the perfection of spiritual education is if someone is ma'rifah about God. Religious spiritual have Faith in God in three things, namely (1) Tauhid Uluhiyah is that God most begotten is most right in worship, adhered to, and obeyed; (2) To import Tauhid Karaamah, it is the one true God who created, governs his matters and his proof and who oversees, and (3) immoral Tauhid al-Asma 'was al-Shifah is that each who applies in this nature is derived from the deeds and settings of God, and to him, every end, and from him also begins everything.

The emergence of the Covid-19 must be the manifestation and appearance of Qudrah Iradah Allah, who is the creator and the regulator (Tauhid Rububiyah). $\mathrm{He}$ is the one who makes and he who will make him (Tauhid al-Asma ' wa alShifah). For this, according to Said Aqil Siraj, people who have the spirituality of religion struggle by imploring God to be given salvation for all people on Earth regardless of race, religion, or nationality. In religious studies, there is a mechanism of praying. They no longer see anything other than God. Everything other than God does not exist, non-existence. "It is only a matter of Coronaviruses, on-off

${ }^{47}$ Maragustam, Pembentukan Karakter Anak Bangsa Perspektif Filsafat Pendidikan Islam (Yogyakarta: FITK UIN Sunan Kalijaga, 2019), 138. 
affairs themselves, the fate and future of the world and the Hereafter; they do not care. No one is more important than Dzat Allah, "Therefore, if we cannot take the road, Taqarrub and Tahaqquq then choose Ta'abbud Road. "Fight loudly with this pandemic, be willing to obey the government's appeal and paramedic advice, and apply more supplication to God, the Almighty Creator, by praying and hoping to get right and kept away from the ugliness. With the Covid-19 exam, the spiritual-human heart is tested to be closer to God. Besides, it is more meaningful to the presence of God, scraping pompous, enhancing the meaning of patience, bringing humility, requiring God, remembering human limitations. It also increases the sensitivity of the heart down the reach of God, who can create anything in this natural sheet and believe in God's infinite power. From here, there needs to be a change of spiritual radical and an excellent human heart. It is in line with Erich Fromm's opinion quoted by Paulinus Yan Ollah that human sustainability, both physically and as a species, depends on the human heart's radical changes. ${ }^{48}$

The second is the dimension of intellectual education. According to Ibn Qayyim, intellectual education exerts power and ability to develop resourcefulness, educate and expand insight and horizon thinking. ${ }^{49} \mathrm{Al}-\mathrm{Munaw}$ ar says that the dimension of intelligence in a psychology view is a process that includes three methods: analysis, creativity, and practical..$^{50}$ The intellectual process of human beings is the study, research, and experiment of childbirth. Now, doctors, medical personnel, and drug experts worldwide struggle to find the solution, prevention, and termination of the new illness, including finding vaccines for this Covid-19. The doctors found reducing the risk of contracting the Coronavirus with; (1) Often wash hands with soap and water flowing at least 20 seconds, (2) Wash hands using soap when arriving at home, workplace, or school, before meals, before preparing meals, and after using the toilet, (3) Use a hand sanitizer (at least $60 \%$ alcohol) when soap and running water are unavailable, (4) mouth and nose shut with elbow folded when coughing or sneezing or using tissue, which is directly dumped into the trash closed after use. After that, wash your hands with soap and water flowing or liquid hand sanitizer, (5) keep a minimum distance of one meter with an unhealthy person, (6) avoid touching the face, and (7) avoid doing as a substitute, wave, or smile. While curative, the experts have not found a vaccine to cure the Covid-19 outbreak until the papers are written.

${ }^{48}$ Paulinus Yan Ollah, "Mengapa Derita Ini?,” Kompas, 2007, 6.

${ }^{49}$ Hasan bin Ali Hijazi al, Manhaj Tarbiyah Ibnu Qayyim (Jakarta: Pustaka al-Kautsar, 2001), 158.

50 Said Agil Husin Munawwar al, Aktualisasi Nilai-Nilai Qur'ani Dalam Sistem Pendidikan Islam (Jakarta: Ciputat Press, 2005), 9. 
The third is the dimension of social-affective education. It is the ability to understand and feel what is experienced by the disaster and the ability to read the feelings of others or the social situation where the disaster is and respond appropriately. The response can be sympathy (a process by which someone is interested in other parties, feeling experienced, done, and suffered by others). It can also be empathy (do something to others, using the way of thinking from others, which, according to others, it is fun and right). In a Hadith, it is mentioned: Imperfect Faith one of you so that he loves and loves his brother as he loves himself. " (HR. by Imam al-Bukhari). About the others in truth, Syaibani says that emotion (affectation) brings the love of winning the truth and the willingness to sacrifice a physical soul and treasure to defend the truth. This affective essence is the love of kindness. His advice is compassion, and his terrace is the purpose of happiness to the whole man. ${ }^{51}$ As a social implication of this affective education's value, when the Covid-19 disaster befalls a person, everyone must demonstrate his responsibilities to overcome them according to their skills and abilities. Someone who has a wealth of sharing with his wealth, which knows about providing guidance and action to overcome it, the healthy is not approaching the sick, and so on because the consequences of disasters befall the sin and the innocent (al-Anfal [8]: 25). In a Hadith, it is mentioned: indeed, man, when he sees the wrongdoers, the calamity, the disaster, they do not take any action or hesitation, God will suffer the calamity and distress to them in general. (HR by Imam Turmudzi).

The fourth is the education of psychomotor value, which includes the behavior of physical movement and coordination, motor skills, and a person's physical abilities. Psychomotor education about the Covid-19, according to Muslimah, is the improvement of the immune system to fight Covid-19. It can be done by consuming four healthy, nutritious food five perfect. Also, it is suggested to sunbathe in the morning, exercise routine, take adequate rest, have a clean and healthy lifestyle by handwashing soap in flowing water for at least 20 seconds, and reduce direct contact (social distancing), avoid or do not smoke and others. ${ }^{52}$ Islam inspires the importance of physical education - with the guidance of cleanliness, bathing, ablutions ', prayers; it must be sacred from the unclean when performing prayers; even the sexual intercourse pays attention to this physical education (QS. Al-Baqarah: 187 and 222).

${ }^{51}$ Omar Mohammad Syaibani al, Falsafah Pendidikan Islam (Jakarta: Bulan Bintang, 1979), 135.

52 Abdul Arif, "Wajib Baca, Tips Tingkatkan Sistem Imun Untuk Tangkis Covid-19," AyoSemarang.Com, April 2, 2020, https://www.ayosemarang.com/read/2020/04/02/54679/ wajib-baca-tips-tingkatkan-sistem-imun-untuk-tangkis-covid-19. 
From the dimensions of the results, that the human being a character or not characterized, it is already an integral part of him and equipped with an environmental coating. The four areas of Islamic education above require high discipline from everyone to reduce the risk of the Covid-19 outbreak by adhering to the health protocol. But there is no inevitable society that is less disciplined because of a particular cause. It is in line with the opinion of Syafi' $i$ Ma'arif as quoted by Aloys. It is said that indiscipline has made some people have prolonged numbness, regardless of the big problems about the future of this nation. Pragmatism, greed, and insight too short have caused us to lose the perspective of the future..$^{53}$

\section{CONCLUSION}

The word of plague can be traced through three keywords. They are bala, slander, and calamity. The outbreak of Covid-19 can be due to God's direct power or because of human behavior. The purpose of the plague was not to torment man but as a test of God. That is, for man to be close to God, to be more meaningful to God's presence, to erode pride, to increase the quality of Faith, to humble, to need God, to remember limitations, to increase sensitivity, and to strengthen the boundless confidence in God. The theory of Islamic education uncovering the plague is positively active and dual-active. The implication of the principles of Islamic education facing the plague is that one does not approach where the plague occurred. If he is at the plague site, do not go out of the location; the sick do not mix with the healthy; do not harm oneself and others. Close the harm takes precedence over taking advantage. Simultaneously, the Islamic educational values of the Covid-19 outbreak are religious, cognitive, affective, and psychomotor education.

${ }^{53}$ Aloys Budi Purnomo, "Bangsa Penuh Petaka," Kompas, January 4, 2007, https://groups. google.com/forum/?nomobile=true\#!msg/milismediacare/GMc4Kc4E4JI/WbjwpZNMRGYJ. 


\section{REFERENCES}

A., Djazuli. Ushul Fiqh Metodologi Hukum Islam. Jakarta: PT RajaGrafindo Persada, 2000.

Ahmad, Zohaib, and Arzoo Ahad. "COVID-19: A Study of Islamic and Scientific Perspectives." Theology and Science 19, no. 1 (January 2, 2021): 32-41. https://doi.org/10.1080/14746700.2020.1825192.

Ahmadi, Basuki, and Edi Irawan. "The Internalization of Attitude and Values: Comparison Study in PTKIN and PTKIS.” Cendekia: Jurnal Kependidikan Dan Kemasyarakatan 18, no. 1 (May 16, 2020): 17-32. https://doi. org/10.21154/cendekia.v1i1.1761.

Amin, Ma'ruf, and M. Nasruddin Anshori CH. "Pemikiran Syekh Nawawi AlBantani,.” Pesasntren No. 1 Vol. VI/1989 (1989).

Arif, Abdul. "Wajib Baca, Tips Tingkatkan Sistem Imun Untuk Tangkis Covid-19." AyoSemarang.Com, April 2, 2020. https://www.ayosemarang. com/read/ 2020/04/02/54679/wajib-baca-tips-tingkatkan-sistem-imununtuk-tangkis-covid-19.

Arif, Mahmud. "A Critical Conceptualization with Special Reference to AlKillni's,” n.d., 12.

Azra, Azyumardi. Pendidikan Islam, Tradisi Dan Modernisasi Menuju Milenium Baru. Jakarta: Logos Wacana Ilmu, 1999.

Bantani al, Syekh Nawawi. Murah Labiid Tafsir li Kasyf Ma'na Qur'an Majid. Vol. Juz 1 dan 2. Mesir: Dar Ihya al-Kutb al-Arabiyah li Ashhabiha 'Isa alBab al-Halabi wa Syurakah, tt.

—. Tanqih Al-Qaul al-Hatsits Fi Syarh Lubab al-Hadits. Semarang: Thaha Putra, tth.

Bappenas RI, Kementerian Negara PPN /Bappenas RI. Rencana Aksi Nasional Pengurangan Resiko Bencana 2006-2010. Jakarta: Bappenas dan Bakornas PB, 2006.

Endarmoko, Eko. Tesaurus Bahasa Indonesia. Cetakan kedua. Jakarta: PT Gramedia, 2007. 
Fadly, Wirawan, Fatkul Jannah, Omnia S. Ahmed, and Diah Susanti. "Diagnostic Skill of Internalization-Interconnection Qur'ani With Science in Three Levels of Madrasah." Cendekia: Jurnal Kependidikan Dan Kemasyarakatan 18, no. 2 (December 10, 2020): 267-89.https://doi.org/10.21154/ cendekia.v18i2.2178.

Hijazi al, Hasan bin Ali. Manhaj Tarbiyah Ibnu Qayyim. Jakarta: Pustaka alKautsar, 2001.

Hurgronje, Snouck. Mekka, Tn The Latter Part Of The 19TH Century. Leiden: Brill, 1931.

Ma'luf, Loes. Al-Munjid Fi al-Lughah Wa al-A'lam. Beirut: Darul Masyriq, 1987. Maragustam. Filsafat Pendidikan Islam Menuju Pembentukan Karakter. Yogyakarta: FITK UIN Sunan Kalijaga, 2020.

- Pembentukan Karakter Anak Bangsa Perspektif Filsafat Pendidikan Islam. Yogyakarta: FITK UIN Sunan Kalijaga, 2019.

. "Bencana Dalam Al-Qur'an (Pemikiran Pendidikan Al-Qur'an Berbasis Bencana)." Jurusan Tafsir Hadis Fak. Ushuluddin UIN Sunan Kalijaga 8, No. 1 Januari 2007 (2007). http://digilib.uin-suka.ac.id/24133/1/bencana\%20 dalam\%20alquran-maragustam\%20fix.pdf.

Munawwar al, Said Agil Husin. Aktualisasi Nilai-Nilai Qur'ani Dalam Sistem Pendidikan Islam. Jakarta: Ciputat Press, 2005.

Nasution, Harun. Teologi Islam, Aliran-Aliran Sejarah Analisa Perbandingan. Jakarta: UI-Press, 1986.

Noer, Deliar. Gerakan Moderen Islam Di Indonesia 1900-1942. Jakarta: LP3ES, 1982.

Ollah, Paulinus Yan. "Mengapa Derita Ini?” Kompas, 2007.

Poerwadarminta, W.J.S. Kamus Umum Bahasa Indonesia. Edisi III. Jakarta: Balai Pustaka, 2005.

Purnomo, Aloys Budi. "Bangsa Penuh Petaka." Kompas. January 4, 2007. https://groups.google.com/forum/?nomobile=true\#!msg/milis-mediacare/ GMc4Kc4E4JI/WbjwpZNMRGYJ.

Rahmatullah, Azzam Syukur, and Muhammad Azhar. "Pendidikan Spiritual Berbasis Tasawuf(Upaya Meminimalisir Perilaku Menyimpang Homoseksual 
di Pesantren)." Cendekia: Jurnal Kependidikan dan Kemasyarakatan 17, no. 2 (November 5, 2019): 235-52. https://doi.org/10.21154/cendekia. v17i2.1746.

Riyadi, Hendar. "Koeksistensi Damai Dalam Masyarakat Muslim Modernis." Wawasan: Jurnal Ilmiah Agama Dan Sosial Budaya 1, no. 1 (February 1, 2016): 18-33. https://doi.org/10.15575/jw.v1i1.575.

Sabiry, Mas'ud. Fatawaa Al-Ulama Haula Firus Corona. At Tawzi' Wa al-Nasyar, 2020.

Shae, Ega Almira. "Virus Corona: Penyebab, Cara Pencegahan Dan Dampaknya Pada Ekonomi Global Avatar." Koinworks, 2020. https://koinworks.com/ blog/virus-corona/.

Shihab, M. Quraish. Corona Ujian Tuhan Sikap Muslim Menghadapinya. Ciputat Tengerang Selatan: PT. Lentera Hati, 2020.

Suyadi, Zalik Nuryana, and Niki Alma Febriana Fauzi. "The Fiqh of Disaster: The Mitigation of Covid-19 in the Perspective of Islamic EducationNeuroscience." International Journal of Disaster Risk Reduction 51 (December 1, 2020): 101848. https://doi.org/10.1016/j.ijdrr.2020.101848.

Syaibani al, Omar Mohammad. Falsafah Pendidikan Islam. Jakarta: Bulan Bintang, 1979. 